\title{
ПОИСК 2-ОКСИНДОЛЬНЫХ ИНГИБИТОРОВ АЛЬФА-ГЛЮКОЗИДАЗЫ
}

\section{О.С. Киктева', И.А. Пешкурова', В.Г. Клочков', Е.Н. Безсонова², Д.Д. Мелехина ${ }^{2}$ М. Дубар²}

${ }^{1}$ Кафедра фармакологии и биоинформатики, ФГБОУ ВО ВолгГМУ Минздрава России, 400131, Россия, Волгоград, пл. Павших борцов, 1.

${ }^{2}$ Кафедра медицинской химии и тонкого органического синтеза химического факультета, ФГБОУ ВО МГУ, 119991, Москва, Ленинские горы, дом 1, строение 3, ГСП-1.

DOI: 10.19163/MedChemRussia2021-2021-350

E-mail: olusha_kik@icloud.com

Изучено влияние 24 новых производных 2-оксиндола на активность альфа-глюкозидазы [1]. Выявлено 6 соединений, оказывающих большее ингибирующее действие на альфа-глюкозидазу в концентрации 100 мкМ, чем препарат сравнения (Акарбоза); 4 исследуемых производных (К-170(1), $\mathrm{K}-127, \mathrm{~K}-165$ и K-248) превосходят акарбозу по величине показателя $\mathrm{IC}_{50}$. Показано что производные 3-арилиден-2-оксиндолов при наличии в положении C3 $\left(\mathrm{R}^{1}\right)$ карбоциклического радикала с заместителем в пара-положении и в положении С5 амидной группировки возрастает ингибирующая альфа-глюкозидазу активность веществ. Выявлено соединение К-170 (IC $=6,78$ мкM), превосходящее по активности соединение сравнения (IC 50 436,70 мкM).

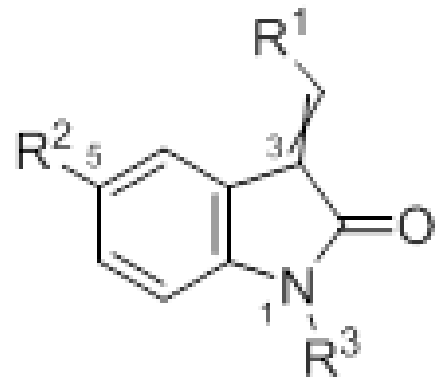

Рис. 1. Структурная формула изученных веществ.

Соединение К-170(1) оказывает достоверный антигипергликемический эффект (п/о, 5 мг/кг) в тестах толерантности к дисахаридам (мальтозе, сахарозе); влияния на уровень постпрандиальной гипергликемии в тесте толерантности к глюкозе выявлено не было, что подтверждает выявленный механизм действия изучаемого соединения.

\section{Литература}

1. Лозинская Н.А., Зарянова Е.В., Бабков Д.А., Клочков В.Г., Спасов А.А., Ефремов А.М., Безсонова Е.М. Ц.М.Д. Патент №2734495 Способ лечения сахарного диабета. 2020. 